\title{
The relationship between education and learning and its consequences for dialogic pedagogy
}

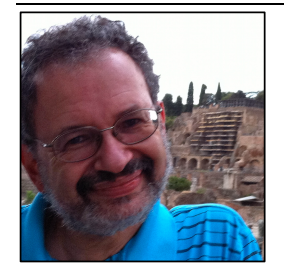

Eugene Matusov

University of Delaware, USA

\begin{abstract}
Education is often viewed as formalized learning. I argue that the relationship between education and formalized learning is more complex and profound. In this conceptual essay, I examine the relationship between education and learning. Specifically, I discuss the cases when learning is not education and education is not learning. I argue that learning becomes educational when the person, the learner themselves, appreciates their learning. When learning is not appreciated by the learner, it does not constitute that person's education. Thus, education is an ephemeral subjective construct, prone to appear and disappear as the person's attitude to their learning changes. Also, education can be non-learning-based when it involves insights - abrupt, discontinuous changes of the person's subjectivity which are not caused by and rooted in the person's experiences. Like learning, for an insight to be educational, it has to be perceived and appreciated by the person. I argue that human life consists of the flow of learning and insight. Noticing learning and insight by the person involves discontinuity of the person's subjectivity, participation in activities, and other people that is recognized by others and the person. I discuss diverse forms of the person's appreciation of learning and insights that constitute education. These forms vary from the behaviorist appreciation, as its lowest form, to the critical appreciation through critical dialogue as its highest form. Finally, I consider the consequences of defining education through a person's appreciation of the transformation of their subjectivity for dialogic pedagogy.
\end{abstract}

Eugene Matusov is a Professor of Education at the University of Delaware. He studied developmental psychology with Soviet researchers working in the Vygotskian paradigm and worked as a schoolteacher before immigrating to the United States. He uses sociocultural and Bakhtinian dialogic approaches to education. His recent books are Matusov, E. (2017). Nikolai N. Konstantinov's authorial math pedagogy for people with wings, Matusov, E. \& Brobst, J. (2013). Radical experiment in dialogic pedagogy in higher education and its Centauric failure: Chronotopic analysis, and Matusov, E. (2009). Journey into dialogic pedagogy.

\section{Acknowledgments}

I am very thankful to Ana Marjanovic-Shane and Je'anna Clements for their discussions and editing prior drafts of the essay.

\section{2es}

\section{Introduction}

Education is often viewed as formalized, institutionalized, well-defined, and preset learning, limited in time. Through educational learning, a society passes on the important knowledge, values, and skills from 
one generation to another (e.g., Resnick, 1987). From this perspective, learning is a process through which education - defined as the student's acquisition of the knowledge, values, and skills pre-selected by the institution, society, or teacher - occurs. From this perspective, education differs from learning because education is an institutional process, while learning is a psychological process. Thus, self-education is a misnomer because it is only the society, through its institutions, that can preset important curricula that define education. Only instruction - i.e., a form of guidance toward the important curricula, preset by the society - can be self-promoted, not education itself. Furthermore, from this point of view, education involves a societal judgment of what is good for students to study. "Education is something that one gets from a school or university; education is related to classroom learning, and some other set standards. On the contrary, learning evolves at the personal level, for which there are no set standards." According to this conventional paradigm, learning becomes educational only when it is appreciated by the society. Of course, "the society" is an abstraction - politicians, educational bureaucrats, educational experts, school administrators, teachers, and parents often talk on behalf of "the society." The "voice" of the "the society" is not always coherent ${ }^{2}$. Nevertheless, the hegemony of this paradigm is a powerful social and educational phenomenon in its own way. The realness and power of a social construction do not require it to reflect the "out-there" reality.

But there is another, not less important, view of education. Here I want to bring this different understanding of education in focus through the following example. When I ask my undergraduate students, future teachers whether the notions of "a good student" and "a good learner" are the same or different - all my students claim that they are different. From the conventional perspective described above, 'a good student' and 'a good learner' must be, or, at least, can be the same. In contrast, my students say that "a good student" is one who gets good grade marks, succeeds on exams and tests, follows the teachers' instructions, answers correctly the teacher's questions, submits all homework on time, punctual, good behaving, polite, accurate, often raises their hand ready to answer on the teacher's question, pleases the teacher, and so on. In short, "a good student" meets the institutional expectations. In contrast, according to my students, "a good learner" is one who learns what is interesting for them, who initiates their own learning, who chooses what to learn and what not to learn, is very active, brings learning initiatives, can disagree with the teacher, is knowledgeable and skillful much beyond what school requires (and even what the teacher knows), can be difficult for the teacher, can refuse to study what the teacher wants them to study, can be disruptive in the classroom, etc. In other words, "a good learner" is self-directed, defining education for themselves. Many of my students are ambivalent about who is preferable for them as future teachers: "a good student" or "a good learner." They like "a good student" for being cooperative but dislike them for being somewhat dull. They like "a good learner" for being passionate about their own learning and studies, but my students are frightened a bit by "a good learner" for being potentially uncontrollable and "too knowledgeable." As one student of mine said, "' A good student' is easy, but 'a good learner' is more interesting."

\footnotetext{
${ }^{1}$ I found this interesting short article by an unknown author on the Internet summarizing rather well the relationship and the contrast between education and learning from the conventional perspective: $h$ ttp://www.differencebetween.net/miscellaneous/differencebetween-education-and-learning/.

${ }^{2}$ I am thankful to Je'anna Clements for raising the issue. She wrote on the margin of the previous draft, "There's a problematic hidden premise here in that it assumes that there is such a thing as a 'society' which can have coherent values by which to 'appreciate' something or not 'appreciate' something in a definable way. In my experience there is no clear 'societal judgment' of what is good to study. Huge majorities grumble about why do we teach our kids Pythagoras but not tax returns etc. I do not agree that the curriculum is set by 'society' except in that the majority will expect what they have seen before, so that once a curriculum is set, future cohorts expect it to look similar to what it did before. It is initially variously set by politicians, academics and other very small but powerful niches that have managed to monopolise it."
} 
In one of my past classes, a student raised a very interesting question, "Can 'a good learner' be 'a good student'?" Initially, many of my students replied affirmatively, "Oh, yeah. It's possible when the teacher's curricula coincide with the learner's interests." I remember a student who said that for 'a good learner,' school studies are the bare-bone minimum. 'A good learner' often studies a lot outside of school. Nevertheless, 'a good learner' can be 'a good student' by doing well on the school tests and exams because they usually know more than the rest of the class. This makes school studies a bit boring for 'a good learner' who is also 'a good student.'

However, as our discussion progressed, some students led by the student who raised the original question started to disagree. That student argued, "'A good learner' can only pretend to be 'a good student.' But 'a good learner' cannot TRULY be 'a good student.' Because 'a good learner' decides by herself what to study, while 'a good student' submits to the teacher who decides what to study. 'A good learner' thinks for herself [what to study, what is education], while 'a good student' delegates it to the teacher." Another student continued that for 'a good learner' to pretend to be 'a good student' is always painful because they have to do something that goes against their nature to look like 'a good student.' She remembered how in her past school, she had to do boring class and home assignments instead of doing exciting activities she truly wanted to do to the point that she stopped wanting to do them. "When I was in elementary school, I loved to write poems and stories. But in my middle school, I learned to hate writing. I received an ' $A$ ' in English throughout all my school career, but I do not like to write anymore, except, maybe, for my diary and social media." She said that she still felt sad that she betrayed herself as an emerging writer for getting good grades in school. She ended up her story by admitting that she pretended to be 'a good student' so well she eventually became one - "a school zombie," as she put it.

Yet, some other students in the class disagreed, arguing still for a possibility of "a happy marriage" between these two positions: 'a good learner' and 'a good student.' They could not provide good examples that could survive the scrutiny of the other group and, thus, admitted that this "happy marriage" was difficult to achieve, and it remained an uneasy one - a happy but uneasy marriage.

It took me years to realize how profound this discussion was. Together with my two colleagues Renee DePalma and Mark Smith - I studied students from an innovative, progressive K-8 school who went to conventional high schools (DePalma, Matusov, \& Smith, 2009; Matusov, DePalma, \& Smith, 2010). Many students reported this dilemma to us about how to pretend well to be 'a good student' without losing their own soul of being 'a good learner.' They used many creative strategies to achieve that - "smuggling learning into school context" - but still, as one student eloquently put it, "They suck life out of you" (DePalma et al., 2009 , p. 945). Education to be authentic must be decided by the student, not by the teacher, by the school, or by the state. Learning becomes educational only when it is appreciated by the learner (Matusov, 2020c, 2020d):

Good learning becomes education, bad learning is not. Who makes this evaluation? In my view, it must be first and foremost "the student" - i.e., a person who learns. Of course, other people might disagree. A teenager, who learns how to binge drink, may call this learning education, while his mother may disagree. Education can be contested (Matusov, 2020c, pp. SF103-SF104).

\footnotetext{
${ }^{3}$ At the lesson, I missed a teaching-learning opportunity to ask my students the reverse question, "Can 'a good student' be 'a good learner'?" I think this reverse question problematizes the notion of 'a good student' much more dramatically than the original question raised by my student. However, I sense that her original question was more important for them - ontologically, existentially,- than my reversed question.
} 


\section{When learning is and is not education}

Not all learning is educational. Learning can be anti-educational - for example, so-called 'learned helplessness' - a sense of powerlessness that a person learned through many, usually traumatic, experiences of failure to achieve something important for the person. The American behaviorist psychologists Martin Seligman and Steven Maier coined this term in 1967 when they tried to make sense of their experiments on dogs who learned that they couldn't escape the electrical shock stopped trying in subsequent experiments, even when it became possible to avoid the shock by jumping over a barrier (Maier \& Seligman, 1976, 2016). Learned helplessness has been found in humans and associated with such unpleasant conditions as low self-esteem, self-worthlessness, anxiety, depression, and even post-traumatic stress disorder.

However, the critical review of the concept and numerous studies of learned helplessness by the educational psychologist Sandra Mark revealed, among many other flaws, an assumption uncritically accepted by many researchers of learned helplessness that a person's perseverance in the face of difficulties is always good while giving up is always bad:

"Learned helplessness" is not a term one would use to describe a person being recommended or praised, nor is the term "underachiever." It has been assumed that learned helplessness and underachievement are behaviors that need to be changed because they are detrimental to the individual and thus are maladaptive. This assumption may not be entirely valid in all situations because it has not been investigated. One can just as well assume that if a person exhibits learned helplessness or underachievement, then it is for reasons that bring a degree of relief and is therefore adaptive. The relief may be from competitive strivings, from family pressures, from the need for peer acceptance and approval, from the need for social acceptance by the opposite sex, etc. Maladaptiveness may be a construct in the eye of the investigator only! (Mark, 1983, p. 9).

In one of my past undergraduate classes, I had a student, a future teacher, who I had thought had "learned helplessness." She was disengaged in my class on cultural diversity in education despite my diverse pedagogical approaches to engage her and despite her own public pronouncements in the class that she wanted to learn to be a good teacher. Although it might sound a bit disrespectful, the student can be compared with Seligman and Maier's dog, who wanted food but stopped trying to get it. For example, during our practicum at a local community center, I used to send little children to her to ask for help with their playful activities, but this student rejected those children - she continued texting on her smartphone or distracting her peers from working with children. To my big surprise, a year after, while bumping into each other on the campus, this student admitted that our class was the best thing that happened with her at the university. "How come?!" asked I. She explained that in my class and through my efforts to engage her in studies and in working with kids and through her negative, "learned helplessness" response to that, she painfully realized that she did not want to be a teacher. Instead, she changed her major to acting, and she felt happy there. She concluded that it was important for her to listen to herself rather than always force herself to engage in educational studies. Giving up teacher education was the best learning that happened with her. In her case, "learned helplessness" - a lack of the student's study action, engagement, and motivation aimed at becoming a good teacher, despite the student's own learning desire - was educational because she, the learner, came to appreciate it. "Learned helplessness" was how she and I framed her experiences in the class and immediately after (see below). Nevertheless, later, the student's "learned helplessness" to study how to become a teacher became educational because the student's reluctance to study was reinterpreted as having a wrong learning desire in the first place. 
As her teacher, I learned that my pedagogical role was not always to engage my students in the studies - even if they had chosen these studies - but, importantly, also to test their motivation and commitment to it. The lack of motivation and commitment might be an important sign that their initial educational desire might be wrong. The presence of education is defined by the value the learner attributes to their learning. If this value is negative or neutral, the underlining learning is not educational for the learner (a neutral value), or it even can be anti-educational (a negative value). Only when the learner attributes a positive value to their learning, the learning becomes educational for the learner. For the student I described above, the value of her "learned helplessness" apparently changed from seeing herself to be "a poor, unmotivated, preservice teacher" (as she told me. see below) to finding her own calling as a future actress. Her subjective attitude to her learning disengagement has changed. In our class, she apparently saw her disengagement with the class studies and children - her learning how not to engage despite my pedagogical efforts - negatively. She had learned that she was a bad student of teaching, However, sometime later, she started seeing this disengagement positively as a sign that teaching was not her vocation. She had learned that acting and not teaching was her vocation. Her "learned helplessness" changed from being anti-educational to becoming educational.

Similarly, my colleagues and I got a similar finding in our cross-cultural study of "instrumental learning"4 and "ontological learning"5 based on important learning experiences reported by our research participants (Matusov, Baker, Fan, Choi, \& Hampel, 2017). To simplify the study a bit, "instrumental learning" is one where the outcome and not the process is most important for the learner, so a person would be happy to shorten this learning experience as much as possible. In contrast, "ontological learning" is one that the process is more important for the learner than its outcome - the person would NOT want to shorten the learning experience. The researchers hypothesized that the nature of the learning - whether it is instrumental or ontological - is defined by its content of the learning. For example, learning mechanics of photography would be perceived by the learner as "the instrumental learning," while learning the art of photography would be perceived by the learner as "the ontological learning." To test this hypothesis, we abstracted the descriptions of the participants' learning experiences, cleaning them from any judgments by the participants, and asked two "blind" coders to judge if it were "instrumental" or "ontological" learning. If our hypothesis had been correct, we would have gotten a high, statistically significant degree of agreement between the coders and our research participants. To our big surprise, the agreement was very low. Thus, it appears that the nature of the learning experiences is not defined by the learning content but rather by the participant's subjective attitude to it (Matusov et al., 2017). For example, for one participant we interviewed, learning the technical aspects of photography was instrumental, while for another participant, this technical learning was ontological:

[Would you shorten learning the technical aspects of photography?] I do not think so because [otherwise if I shorten it then] I could know nothing in high school and pick up a class and know all this technical information but I would not have a natural progression because photography gives you this progression I would have the same results but not the sense of accomplishment because I would not be able to see the progress of it (Anne, US, young adult, HS diploma +) (Matusov et al., 2017, p. 465, bracketed insertions are mine).

In sum, education is an ephemeral, changing, subjective construct of the learner's positive evaluation of their own learning.

\footnotetext{
${ }^{4}$ Je'anna Clements: "corresponds to Autonomous extrinsic motivation." I respectfully disagree with the equivalency of our terms because it is not the local of the motivation was at stake but its quality: the focus of the learner's appreciation of the product or the process.

5 Je'anna Clements: "corresponds to Autonomous intrinsic motivation." See my comment above.
} 


\section{Non-learning education through insights}

I started reading when I was two months short of becoming a 10-year-old. With a high probability, it was a case of undiagnosed dyslexia. My son, who was formally diagnosed with dyslexia, started reading around 10 -year-old as well.

I remember vividly that I went to sleep not being able to read - it was a homework poem that we were supposed to read out loud in the class the next day - I anticipated another torture of me publicly messing up the poem words in the classroom. I woke up and looked at the text, and oh, magic, I could hear the voice of the poem. I leafed through the pages of the textbook to check other texts - the magic was still there. I could hear the voices of the texts just by looking at them. Before that memorable morning, "reading" was a difficult process of deciphering alien symbols. Actually, it wasn't even that... Let me share our family lore that made my parents cry, laugh, and be frustrated.

My mom, dad, and seven-year-old me were sitting around a family-room table and taking turns to "read" aloud the fairytale "Puss in Boots." My mom and dad read a page while I had to read a paragraph the shortest on the page, I loved stories and storytelling, but I hated this torture by "guided reading" (I was reading in Russian, my native language, this is a compatible translation):

My mom: Dear, with what letter does this word start?

Me (nailing the letter "H" with my index finger): "Aich."

My mom: Good. Here it reads as "kh." And the next letter? What's the sound?

Me (I'm thinking, how does mom know that this time it reads like "kh"?! Strange. Moving my finger to the letter "a" ): "Ai."

My dad: Hmmm, "æ."

Me (focusing on the letter "a," thinking: "Why 'æ'? - how does dad know that? But whatever." ): "æ."

My dad: So, what will it be together?

Me: "Aichai?"

My dad: No, remember it is "kh" and "æ." What will it be together?

Me: "Khæ."

My mom: Good, sweaty. And the last letter? How does it sound?

Me (shifting my finger to "t"): "Ti."

My dad corrected me: "t." And what you will get together. Add together "kh," "æ," and "t." What will you get?

Me (with a great effort): "kh," "æ," and "t"... - together is... "coat."

My dad exploded: Where do you see "coat"?!!! "Kh," "æ," and "t" together is "HAT"! Not "COAT"!

My mom (hysterically): He is mocking us!

I look at them with a puzzle. What makes them so angry? Back then, I suspected that people lied to me that they could read "texts" - they just memorized stories so well that they could point at the correct "word" - a combination of meaningless, alien symbols. It was all pretense. I just had a bad memory, so I could not do what they could do.

But on this memorable morning that all was gone! I could hear voices by looking at texts. Well, this might be a bit exaggerated. Sometimes the voice stumbled at a difficult word that I had to decipher or simply skip and guess what it might be. But after the deciphering or guessing, I could start hearing the voice again.

What happened during the miraculous night? Did I LEARN reading? I can only guess that my neural network had reorganized somehow in my brain during my sleep. Was it learning? I do not think so. It was 
not learning. Of course, I might learn something important before that night. The miracle that happened with me might have been prepared by my past learning. But this miracle itself was not learning. This abrupt change that happened to me, which I call "insight," was mostly caused by and rooted in my biological change, not in learning per se.

But what is learning? Coming from a sociocultural tradition, I see learning as a transformation of a person's participation in social practice (Lave, 1988, 1992, April; Lave \& Wenger, 1991; Rogoff, Matusov, \& White, 1996). However, in my view, this definition is a bit too broad. A transformation of a person's participation in social practice may be not rooted in and caused by learning but by other factors like changes in other participants, technology, materials, the person's body, weather, mood change, and so on. Learning involves a particular transformation of participation, but not any transformation of participation. For example, losing a leg in a car accident would transform the person's participation in many social practices, but in itself, this transformation won't be learning, although it might spark a chain of learning in the person of how to cope with this challenge.

So, I have to clarify the initial definition in the following way. Learning is a person's transformation of participation in an activity or practice that is mostly caused by and rooted in the person's experience. Based on this definition of learning, the miraculous transformation of my neural network that made me read texts on that memorable morning was not learning because it was not mostly caused by and rooted in my experience. Of course, any learning probably requires and is based on a transformation of the neural network in the brain. But the reverse is not necessarily true that any transformation of the neural network is mainly caused and rooted in learning.

Insights - an abrupt transformation of a person's subjectivity, not caused by and rooted in the person's experiences - can take many forms: epiphany, psychedelic trip, revelation, keisaku ${ }^{6}$, meditation, "shock therapy," paradigm shift, truth dream, throwing yourself in a dramatically different place or situation, awakening, and so on. One can try quickly to experience insight through the so-called "magic eye" - "The art of the eye puzzle is the ability to diverge. This means you look through the image with your eyes, not directly at it. Your eyes move differently if you try to 'look through' a picture. It's an illusion of depth perception that allows a 3D image to suddenly appear in the 2D image"7:

\footnotetext{
6 “In Zen Buddhism, the keisaku (Japanese: 警策, Chinese: 香板, xiāng băn; kyōsaku in the Soto school) is a flat wooden stick or slat used during periods of meditation to remedy sleepiness or lapses of concentration. This is accomplished through a strike or series of strikes, usually administered on the meditator's back and shoulders in the muscular area between the shoulder and the spine. The keisaku itself is thin and somewhat flexible; strikes with it, though they may cause momentary sting if performed vigorously, are not injurious" https://en.wikipedia.org/wiki/Keisaku

${ }^{7}$ https://www.cleareyes.com/eye-care-blog/201802/magic-eye-puzzle-illusions/
} 


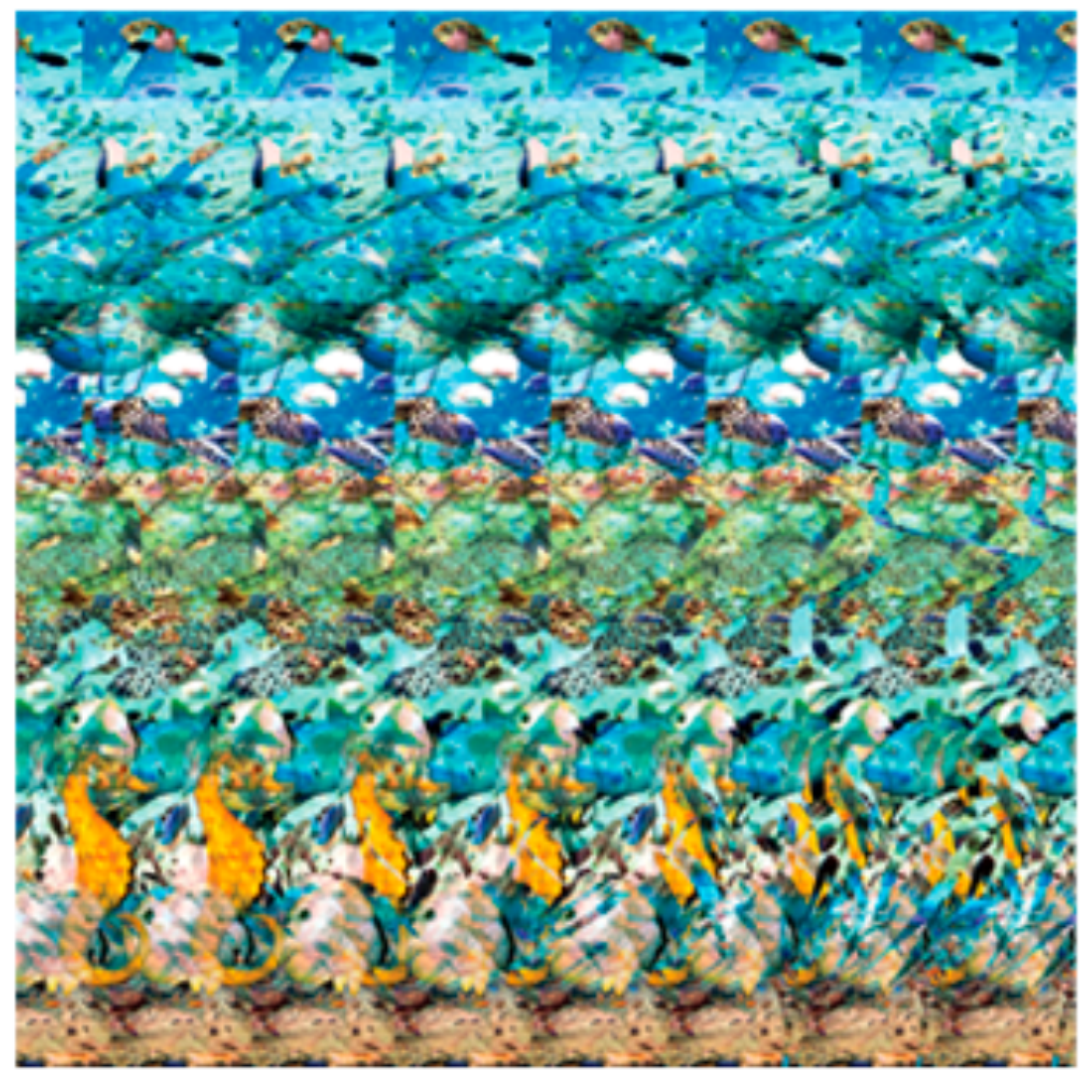

Picture 1: "Behind" this colorful ornament, there is a 3-D picture of the sea world: https://www.magiceye.com/

Although one can learn how to diverge their eyes, the successful divergence from the 2-D ornament that leads to seeing the 3-D picture sea world is not learning, in itself, but rather an insight. For some reason, our ("Western") modern culture does not recognize these abrupt changes of insights and instead focuses mostly on learning. Hijacking the term coined by the educational philosopher Gert Biesta, this cultural phenomenon of totalizing learning can be called "learnification" (Biesta, 2010, p. 5) ${ }^{8}$. Insights are not recognized, understood, appreciated, and pedagogically and culturally mediated.

Not all insights are educational, but only those that are appreciated by the person experiencing the insight. For example, in our research on instrumental and ontological learning, a young American woman reported her accident of falling down from a horse and being paralyzed for one year bedridden. Her life turned upside down. Yet, according to her, it led to her awakening and important revelation about her life. She claimed that she would not shorten this life-threatening painful experience because it made her what she was now. This insight was educational for her (Matusov et al., 2017). In contrast, in the fictional Hungarian novel and movie "The fifth seal" (Fábri, 1976; Sánta, 1986), a character named Photographer

\footnotetext{
8 "I argue that measurement of educational "outcomes" can never replace answering the question of purpose in education, although at times it seems as if this is what those who are engaged in measurement seem to do or seem to aspire to. I relate the marginalization of the question of good education to a phenomenon that I refer to as the 'learnification' of education, by which I have in mind the tendency to replace a language of education with a language that only talks about education in terms of learning. I argue that while learning obviously is one of the central concerns of education, a language of learning makes it particularly difficult to grapple with questions of purpose-and also with questions of content and relationships" (Biesta, 2010, p. 5). However, Biesta argued that it is the teachers, and not learners, who must legitimately define education as appreciation of learning, "What is distinctive about education is not learning - which can happen anywhere, with or without education-but teaching. And the basic gesture of teaching is that of trying to catch and direct the attention of another human being... The teacherly gesture here tries to say no more than 'look, there is something there that I believe might be good, important, worthwhile for you to pay attention to'" (Biesta, 2020, p. 2). I respectfully disagree with him about defining education through teaching.
} 
anonymously reports on four strangers he encountered, to the Hungarian analog of Nazi Gestapo during WWII in order for these "simpletons" to experience an awakening from their mundane and simplistic life (of course, in Photographer's judgment). The only survivor of this "test" was Clockmaker, who did not appreciate the insight organized for him by Photographer. This insight was not educational for Clockmaker.

\section{Recognition of the personal discontinuity}

Let me summarize my discussion so far. First, I discussed the actor of education - i.e., who legitimately defines what education is and what it is not. In contrast to the conventional mainstream perspective (if not paradigm), I argue that the actor of education is the person themselves, one who is involved in education, and not the state, the institution, the teacher, the parent, the educational expert, and so on. The locus of educational control is internal and not external. Second, the content of education is not just the person's learning but also the person's insight. Here, in this section, I will consider the condition of education: when, why, and how the transformation of the person's subjectivity or participation becomes noticed by the person who undergoes this transformation.

According to the conventional views on learning, heavily influenced by particular school learning, the occurrence of learning is problematic, while its content is not. For example, a student may or may not learn the addition of fractions with different denominators. To check if this learning occurred, usually, a test or exam is administered. At the same time, the content of this learning -- the addition of fractions with different denominators -- is not problematic. It is known, given, and set in advance of the learning process itself. In contrast, the sociocultural anthropologist Jean Lave, who studied learning in the wild, has found that the occurrence of learning is not problematic, but its content is (Lave, 1992, April). People learn all the time: the question is what exactly they learn from their experiences. For example, during the math lesson on the addition of fractions with different denominators, mentioned above, some students may learn the addition, some learn a pattern of actions to please the teacher, some learn that math is boring and not for them, some learn how to smuggle fun activities in the classroom without the teacher noticing it, and so on. The occurrence of this diverse learning is not problematic, but what exactly this learning is about is problematic and has to be investigated. To expand Lave's point to the insight, transformation of the person's subjectivity is a constant flow, whether noticed or not noticed by the person and other people. But it becomes an insight when the person notices this transformation.

As I argued above, education involves the person's appreciation of the transformation of their subjectivity and participation. However, in order for this appreciation to become possible, the person has to notice the transformation of their subjectivity, then evaluate it, and finally evaluate it positively. Thus, education is based not only on reflection of their actions but also on self-consciousness and self-awareness of breaking their identity by becoming a slightly or very different person than before. Only when this awareness of breaking self-identity occurs for the person, evaluation of learning and/or insight can happen. Learning and insight flow is ubiquitous; education is not.

People experience education through their desire (e.g., a person wants to learn car driving) and their recognition (e.g., I recognized that I could read in the example above), or both - through their educational desire and recognition. The latter can be exemplified by the case of my student who changed her mind from becoming a teacher to becoming an actress, see above. Initially, she wanted to learn how to become a good teacher. That was her educational desire. However, later, through her disengagement in our class, she realized that, actually, she did not want to be a teacher, but rather an actress. Even more, during our encounter on a campus street, she praised our class and me as her teacher as a contribution to her education. I could not understand it and asked her to explain. We went to a nearby campus café - my favorite back then. The student told me how she saw our class, her peers, and me. She said that in contrast 
to all other education-major classes of hers, in our class, her peers and I discussed what was on the mind of the students. The class meetings involved a discussion of dialogic provocations that I brought to the class that provoked questions and inquiries in the students, which we pursued. Also, the students brought questions, inquiries, dilemmas, and exciting and troublesome experiences that occurred with them at the practicum at a local Boys' and Girls' Club, where the students played, interacted, and engaged in various activities with minority kids of different ages. At the Boys' and Girls' Club, the students had full freedom to act and interact with the children, except forcing the children to do what they did not want to do. My student saw how I tried to help her peers and her develop their interests, questions, and inquiries related to education and working with the kids. She saw excitement and interest in her peers. She said that she had felt the questioning gazes by her peers and me, "Why are you not excited?! Why are you not interested?! What is wrong?!"

She became increasingly puzzled, frustrated, and even cried as to why she was disengaged and disinterested in studying how to become a good teacher. She told me in the café that in her other educationmajor classes, it was required to say what the professor wanted the students to say. She reluctantly complied, as did many of her peers. The focus, she said, was on guessing and pleasing the professor - the old game that she had learned to play relatively well. So, her experiences in other classes were not problematic to her. In contrast, in our class, she said, the students were free to explore their own interests in becoming teachers. The problem was that she suddenly felt that she did not have an interest in teaching, and because of that, she was very different from her peers. That recognition led her to challenge her initial educational desire.

"But why do you see me as your teacher?" asked I. She replied that at first, it was because I designed this type of course focusing on provoking and pursuing students' interests rather than on transmission of "the correct answers" to the students. Secondly, it was because I tried my hardest to encourage her to reveal and pursue her interests in becoming a teacher, which helped her realize that she had none.

As I was sitting in the café and listening to my student's reflection on her experiences in our class, I had my own insightful realizations - four to be exact. The first realization was that a student's disengagement in their learning could be educational. The second realization was that the goal of my course was not only for my students, future teachers, to learn how to become good teachers within my narrow academic subject of cultural diversity, but also to help my students explore their educational desire of becoming a teacher. My third realization was that my pedagogical practice of grading - summative assessment in education - was professionally unethical (Matusov, Marjanovic-Shane, \& Meacham, 2016). How could I give this student a C?! It felt like pedagogical violence to me, for which I was responsible (Matusov \& Sullivan, 2020). Finally, I realized that by sharing her experiences and reflections involving our class with me, my student became my teacher - I had to actively seek such sharing with my students. I was in a professional and personal crisis - I could not teach as I did before. It felt both very exciting and scary to me back then.

However, recognition of education can occur without an initial educational desire in a person. This recognition is not a trivial event because people are always embedded in the ubiquitous and inescapable flow of learning and insight. When, as a 10 -year-old boy, I woke up being able to read, I vividly remember experiencing a strange phenomenon: as far as I looked at a text, the text immediately generated a voice telling me something. It was effortless on my part. Well, almost effortless - until occasionally, I bumped at a word-obstacle (which I often skipped back then). In other words, I did not feel that " $I$ " was reading - rather, reading happened to me. I did not feel like an actor in the reading activity. I did not have agency beyond 
choosing to look or not to look at a particular text. Instead, I was a prisoner - granted, a willing prisoner of reading. I caught reading like people catch the flu or fall in love. This was a typical phenomenon of the powerful life flow of insight. But, at that moment, it was not education yet. Why not?

As a boy, I did not recognize any change in me. I was the same Eugene, but now texts were talking to me. Education involves a person's perceived (and then, more, appreciated) discontinuity of one's identity. In contrast, I felt the same. Eugene-boy with or without candy, Eugene-boy with or without flu, Eugene-boy with or without reading felt to me as the same Eugene-boy. But, not for long.

Other people around me - my teachers, parents, brother, and peers - noticed the change. My school grade marks dramatically improved, literally overnight, in almost all academic subjects from F-C to B-A, except in music (always an A for my efforts) and (Russian) writing (always a C because of my terrible spelling). My parents found themselves in an awkward situation. A few months before my reading miracle, they reluctantly promised me to buy a puppy if I finished an academic quarter without any "C." My older brother, who overheard my nagging and begging to buy a puppy and my parents' counteroffer, said with sarcasm, "You can even promise him to buy an elephant!" That was how hopeless I was academic-wise. But to everybody's surprise, I finished that quarter without any "C" because, as my mom told me later, the school principal managed to twist my Russian teacher's arms to give me a "B" for writing in order to improve the school academic standing in the district. Now my parents had to buy me a puppy or convince me to get something else. They managed to convince me to get a microscope instead against protests of my older brother, who also wanted a puppy.

I had diverse friends, some of which were F-students like me, some were academically OK students, and one of my best friends was an all-A student. Before my reading miracle, my parents asked rhetorically, "I don't understand what he (i.e., the all-A friend of mine) finds interesting in you. Why is he your friend?!" Now they started raising different questions about my friends, "Why are you a friend with those nogoodniks?! They are a bad influence on you." My teachers similarly changed my sitting arrangement, moving me from sitting with academic underachievers to academic overachievers.

I started experiencing changes in my relations with other people. I stopped begging my older brother to read my favorite books to me. Also, my parents started using me as a role model for him, which disrupted our relationship. I started spending less time playing and watching TV and more time reading books. I had really started "binge reading" - reading non-stop for many-many hours without rest, eat, or even sleep or going to the toilet as if I tried to make up for my time of non-reading all of the past years. From their initial praise and approval, my parents gradually shifted to alarm. They started telling me that I would hurt my eyes and soon would have to wear glasses, which happened a few years later.

The nature of my improvisational storytelling with my yard buddies changed from being mostly TV movie-based to book-based. Reading opened doors to other activities that were not available to me before - I got into building radio-equipment based on reading electronic schemas. This changed my friendships I was getting increasingly nerdy friends. I noticed that my teachers started liking me, praising me more and more. Bullies in school also noticed the change - they learned that they could exploit my new academic successes by demanding to copy my homework or asking me for tutoring. I was increasingly presented with new choices, new values, new relational breakdowns, new temptations, new dilemmas, and new friendships that disrupted the flow of my life. "Am I smarter now than before when I was not reading, as some people around me say? Should I brag about my excellent grade to my older brother? Should I leave behind my friends with whom I feel more and more alienated, or should I put extra effort to keep them? Should I push back when my new friends started dissing my old friends? How should I balance my old, non- 
reading, and new, reading-based, interests?" And so on. The choices, dilemmas, relational breakdowns, and the gazes of people around me demanded from me to take stands on the changes that were thrown on me by reading. I started feeling the discontinuity of me: before and after the reading miracle that happened to me. The realization came to me: I-reading became a different person than I-non-reading. I mostly appreciated this discontinuity between Eugene-without-reading and Eugene-with-reading, although not without some ambivalence ${ }^{9}$.

Education as recognition and then appreciation of personal discontinuity is both a gift from others and a personal internal work of self-reflection. The penetrating gazes of other people awake self-reflection on the personal discontinuity on which education-as-realization is based. Now I will turn to a discussion of the diverse forms of appreciation that cause a person to perceive learning or insight as educational.

\section{The fifty shades of educational appreciation}

Apart from democratic schools, the mainstream and innovative schools heavily rely on foisted education. In those schools, students cannot choose whether to study or not to study - education is foisted on them. In addition to that, what students should study and even what they should learn is designed for the students and imposed on them. Although, in some progressive and dialogic schools, what is learned by students can be emergent and not predesigned. Even in many democratic schools, as soon as students choose to study and ask a teacher (usually called "staff") for help, it is expected that the students must surrender their educational agency and authority on what exactly to study, how to study, and what should be learned (e.g., Greenberg, 1991, pp. 15-17).

A German philosopher Immanuel Kant introduced the concept of "educational paternalism" without coining this term (Kant, 1784). While defining human dignity through autonomy, Kant argued that education must be foisted on uneducated and undereducated, immature, irrational, uninformed, and ignorant people in order for those people to be able to achieve their autonomy and, thus, human dignity later on, when education is done on them. His follower, another German philosopher Johann Gottlieb Fichte went even further, proclaiming that this foisting of education is education in itself, "Compulsion is also a kind of education" (cited in Berlin \& Hardy, 2002, electronic edition). I have critiqued Kantian educational paternalism, foisted education, and education with preset curriculum elsewhere (e.g., Matusov, 2009, 2020c, 2020d). Here I want to discuss how educational appreciation is normatized in mainstream, progressive, and democratic schools.

In mainstream conventional schools, there are two major types of students' normative appreciation of their learning (the non-learning, insight-based education is usually not recognized in modern institutionalized education). The first type can be called "behaviorist appreciation," which involves a system of punishments and rewards for the student so they can appreciate their learning. This system involves grade marks, praises, reprimands, scolding, humiliation, corporal punishment (mostly in the past), disrupting relationships with parents and friends, money payments, diplomas, and so on. The behaviorist normative appreciation completely excludes the student from the substantive and, thus, conditional evaluation of the learning foisted on them by the school. The substantive evaluation is when a student considers whether the content of education is good for them or not. The substantive evaluation is always conditional because sometimes the student judges a particular content of learning to be good and sometimes to be bad or irrelevant. Behaviorism guides educators on how to create a conditional reflex in students. Successful conditioning leads to a projection of pleasure or pain by an organism onto an unrelated

\footnotetext{
${ }^{9}$ Later, when I was 14 I moved to live with my illiterate grandma, who was a very wise woman and the center of our big extended family, my ambiguity increased as I started appreciating the orality and the oral civilization more and more (Matusov \& St. Julien, 2004).
} 
stimulus. For example, a famous Russian behaviorist Ivan Petrovich Pavlov successfully conditioned his dogs to produce saliva in response to a bell-ring in anticipation of food. The dogs had a pleasure response to the ringing, similar to the one they had to food. Similarly, in the successful behaviorist appreciation, the pleasure associated with the reward, and psychological or physical pain, associated with the punishment, has become projected on the academic learning foisted by the school. The student appreciates the school academic learning because it becomes either pleasurable for the student or because it helps the student avoid pain. Thus, like in the case of the Pavlovian dogs, the successful behaviorist educational appreciation must start working even without rewards and punishments when the conditional reflex is firmly established. A student must have pleasure in any school academic learning imposed by the school authority or, at least, appreciate this learning because it helps to avoid pain.

The second type of normative educational appreciation in conventional schools can be called "postponed appreciation" (Matusov, von Duyke, \& Kayumova, 2016). A German philosopher Fichte, mentioned above, articulated it in the following way,

Education, says Fichte quite consistently, works in such a way that "You will later recognise the reasons for what I am doing now." Children cannot be expected to understand why they are compelled to go to school, nor the uneducated - i.e., the majority of mankind - why they are made to obey laws which will presently make them rational and so retrospectively justify such coercion as they may have suffered. This is the task for the State. ... If you ... do not understand your own interests as a rational being, I cannot be expected to consult you or abide by your wishes in the course of making you a rational being. ... I force you to be protected against smallpox though you may not wish it (Berlin \& Hardy, 2002, electronic edition).

The postponed appreciation is also unconditional for the students, but this time it involves the student's agency because it is based on students' unconditional trust in educational authorities. The student appreciates the school's academic learning because the student unconditionally trusts the school authorities that this learning will be helpful for the student in the future.

There are, at least, two major problems with the conventional normative educational appreciation: its effectiveness and its desirability. First, let's consider the issue of effectiveness. The behaviorist appreciation has rather limited success. Very few students become conditioned to have pleasure or become attracted to any school learning without the presence of a reward-punishment system. Most of the students appreciate the pleasure of rewards and the avoidance of pains of punishments but not school learning associated with the rewards and punishments. Even more, some other students do not buy it at all. They ignore or actively reject the rewards-punishments system altogether (Sidorkin, 2002). Behaviorism can be successful in making many students learn but not appreciate this learning. It can be concluded that the behaviorist appreciation is ineffective in making students appreciate school learning. Thus, school learning becomes non-educational, if not anti-educational, since many students dislike it - i.e., appreciate school learning negatively. Thus, Yazzie-Mintz (2006) found that $50 \%$ of US high school students are bored every day in their classes. Hart (2006) reported that $82 \%$ of Californian ninth and tenth graders perceived their overall school experiences as "boring or irrelevant" (p. 2). In our own research of alumni of an innovative school who went to conventional high schools, the alumni reported on this suppression of their academic agencies, as they could compare the regimes of their past innovative and current conventional schoolsas one alumni reports, "[The new, conventional] school sucks the life out of you" (DePalma et al., 2009, p. 950). 


\section{The relationship between education and learning and its consequences for dialogic pedagogy}

Eugene Matusov

The effectiveness of the postponed educational appreciation can be judged by 1) how much students unconditionally trust the school authorities and believe that school learning imposed by the school authorities will be useful for them in the future and 2) how much school alumni find their past school learning useful in their current lives. As the cited research above shows, many students see their school learning as "irrelevant." Also, I do not know of one conventional school that would rely on students' trust in school authorities to appreciate the imposed school learning. Thus, despite its rhetoric, the conventional school itself does not trust in the postponed appreciation as a major form of students' appreciation of the imposed school learning. Instead, the reliance on behaviorist appreciation is omnipresent in conventional schools. I could not find good research on alumni's perception of the usefulness of their past school learning (cf. Hartman \& Schmidt, 1995; Snijders, Wijnia, Rikers, \& Loyens, 2019), but my observation suggests that their perceptions are mixed. In the rapidly changing society, technology, economy, etc., it is very difficult for the State, educational experts, politicians, and teachers to predict what can be useful for a particular student in their future.

But, what if the behaviorist and postponed educational appreciation of conventional schools had been $100 \%$ effective? Would their imagined efficiency have been desirable? What if the behaviorism of the rewards-punishments system could successfully condition all students to love the imposed school learning even without the rewards-punishments system? What if all students had deeply trusted the school authorities that the imposed school learning would be very useful in their future? Is it good for the students' education, as I discussed above? My answer is mostly no. Both behaviorist and postponed appreciation are unconditional - it is expected that all students must like all school learning, regardless of its content. The unconditionality contradicts the inherently selective nature of appreciation - appreciation is a positive bias, existing in the context of a possibility for negative and indifferent biases. When negative and indifferent biases are impossible, as the unconditional normative appreciation of conventional schooling implies, appreciation stops being authentic. It becomes pseudo-appreciation. Genuine appreciation involves a possibility for a person to dislike the experienced learning or to remain indifferent to it. Conventional school denies the legitimacy of such options for their students.

In progressive, innovative schools, students' appreciation of their learning is expected to be rooted in their intrinsic motivation. The pedagogical goal of progressive instruction is to expand the students' genuine interests to cover the imposed curriculum that is designed by the educational experts. This expansion of the students' existing interests can be done through "double psychologizing" the imposed curriculum (Dewey, 1902), exploitation of the student's ignorance (Rousseau, 1979), incorporation of the students' "funds of knowledge" (Moll, Amanti, Neff, \& González, 1992), application of "culturally relevant pedagogy" (Ladson-Billings, 1995) or "the strength model" in contrast to "the deficit model" used in conventional education (Cline \& Schwartz, 1999), and so on. "The Holy Grail" of progressive education is to find "the honest way of teaching" that can make any chosen/imposed curriculum intrinsically motivated for any student at any time (Matusov, 2021, submitted; Matusov, Marjanovic-Shane, \& Gradovski, 2019). This is a paraphrase of the famous motto by a famous American psychologist and educator Jerome Bruner, "....any subject could be taught to any child at any age in some form that was honest" (Bruner, 1986, p. 129). The intrinsic motivation appreciation also has problems with its effectiveness and desirability (Matusov, 2021, submitted). "The honest way of teaching" can be achieved for some students, in some curriculum, sometimes. Also, the intrinsic motivation appreciation is normatively unconditional. In progressive schools, students are supposed to love everything that is taught indiscriminately (Greenberg, 1991, p. 101), which contradicts the essence of authentic appreciation, as I discussed above. What makes the normative educational appreciation in the conventional and progressive schooling pseudo-appreciation is its unconditionality and non-selectivity. 
Free from unconditionality, the behaviorist, postponed, and intrinsic motivation types of appreciation can become authentic. When students have a choice to study or not to study, what to study, and how to study, behaviorist, postponed, and intrinsic motivation types of appreciation can become authentic. For example, a child can be bribed by parents with candy to try a smoked fish that looks unappealing for the child. After the child overcomes the repulsion and tries the smoked fish to get the candy, the child may find out whether they like the taste of the smoked fish or not. If the child likes the smoked fish, they can start eating it out of the pleasure of the fish - thanks to the bribe by the candy. But, if the child does not like the taste of the smoked fish, the bribe helped the child to realize that. In this case, this behaviorist appreciation becomes authentic (Matusov, 2020b).

In democratic schools, several types of normative educational appreciation are expected. The first type is affective appreciation. Students study what they like to study. As a founder of the Sudbury Valley School, Dan Greenberg pointed out, the difference between progressive schools and democratic schools is that in the former, students must love what they study, while in the latter, the students study what they love (Greenberg, 1991, p. 101). The second type is curiosity and interest appreciation. Students study what is interesting for them and for what they find their curiosity. Interest and curiosity are the basis of the students' appreciation of their learning and insight (when the latter is recognized). In both types of appreciation, the learning process has an intrinsically positive value for the student. The third type is socialization appreciation. Students learn because they want to socialize in the desired activity or practice or community (e.g., gaming community, a community of practice). The fourth type is problem-solving appreciation. Students study to solve a problem that they are faced with in some activity important to them. They appreciate this learning because it is useful.

The fifth type of appreciation can be called jumping-through-hoops appreciation. Students learn because, in order to reach something desirable for them, they have to learn how to jump through hoops often bureaucratic hoops set by society. For example, many American teenage students in democratic schools choose to prepare for SAT to get to a college of their desire. These students often know that SAT is a waste of their time, but still, it is important for the students because it opens the door for their dream professions (Rietmulder, 2019). In the fourth and fifth types, the product of learning is more important than its process. In the third type of appreciation, the socialization appreciation, students can prioritize the process or product of learning or their mixture. There can be more types of appreciation in democratic schools. In contrast to normative appreciation in conventional and progressive schools, in democratic schools, educational appreciation is conditional and selective for the students, which makes it authentic.

Finally, critical dialogic education offers another type of appreciation - a critical examination of the student's educational desires. The student's appreciation itself becomes the subject of educational investigation. As I described in the case above, my undergraduate student engaged in a critical examination of whether she really wanted to be a teacher and learn about teaching practice or not. Similarly, in studying the issue of how to suppress bullying in school more effectively, my students can be provoked to study what is their true pedagogical desire in addressing bullying in their future classrooms: should their future students avoid bullying their peers because they are afraid of punishment or because they feel that bullying is wrong, or something else. Some of my students realize that their initial educational desire that they wanted to pursue was wrong. Critical dialogic education rooted in Socrates' motto, "The unexamined life is not worth living" (Plato \& Riddell, 1973), makes educational appreciation itself the subject of its critical examination. 


\section{Conclusion: Education and dialogic pedagogy}

The role of dialogue and pedagogy in the student's educational desire, organization, guidance, and reflection are very important. Educational desire involves the student's desire to study something that the student feels is important for them. However, as I discussed above, a particular educational desire can be problematic for the student. In the case above, my student thought that she had wanted to become a teacher and, thus, to study teaching. However, her experience of disengagement in our class, based on promoting authorial dialogic learning in the students, convinced her that her original educational desire was wrong. Although she did not engage in a dialogue about that with me or her peers in the class, she told me during our meeting in the café that she discussed her feelings and doubts with her friends and parents. After our conversation in the café, I decided to incorporate big and small critical dialogues about my students' educational desires, including doubts and changes, in my classes.

Some students know rather well what they want to study - at least with what to start to study - how to study, with whom, when, and where. Some students need help from a pedagogue to provide them with inspirational choices for what to study and how and with whom. Some other students want the teacher to make all these decisions for them and even push them to study. The latter case is still different from widespread foisted education common in conventional and progressive schools because those students have the right to withdraw their trust-based consent to submit to the teacher's educational design at any moment (Matusov, 2021, in press). As I argue here and elsewhere (Matusov, 2020c, 2020d), foisted education is often non- and anti-educational because it excludes the students from the evaluation of their own learning and insight experiences. A critical dialogue among and with students on the organization of their educational activities, facilitated by the teacher when this facilitation is needed by the students, can be an important part of the students' meaningful education.

As I wrote elsewhere (Matusov, 2020a, 2020b), the teacher's genuine guidance starts with the student asking the teacher for help with their difficulties, questions, and inquiries that the student genuinely owns. From this point of view, there is usually very little genuine guidance occurring in conventional schools because either students do not ask for help or they ask for help about difficulties that they do not own, but rather are foisted on them. In conventional schools, it is often the teacher who asks the students questions - the testing, pseudo-questions, because the teacher knows the answer (Lemke, 1990; Mehan, 1979; Sinclair \& Coulthard, 1975). Yet, in genuine guidance, even when the student asks the teacher for genuine help, it is usually unclear about what kind of help is needed, exactly about what, and how much help the student really needs from the teacher (who can also be the student's peer). This is what a true pedagogical dialogue is about ${ }^{10}$.

Another important role of the teacher (who again can be a peer) is to help the student to recognize a discontinuity of the student's subjectivity and participation in an activity when and if this help is needed by the student. This recognition is a precursor of educational appreciation. The discontinuity may be important to be evaluated by the student because of the new choices the student might be faced with. When I was a 10-year-old and found myself suddenly able to read, people around me - my parents, my teachers, my friends, my peers, and even my new activities - tried to impose their choices on me. I wish I had had somebody who would have helped me make sense of the changes and pressures imposed on me by the newly emerged reading ability. I wish there had been somebody, whom I trusted at the time, who engaged me in a critical dialogue about the discontinuities and relational disruptions my newly emerged reading

\footnotetext{
${ }^{10}$ Here, I am using the term "pedagogical dialogue" very differently from Mikhail Bakhtin, a Russian philosopher of dialogism. Bakhtin used this term descriptively and almost sarcastically to capture the monologic nature of the teacher-student exchanges in conventional schooling (Bakhtin, 1999; see also: Matusov, 2009; Skidmore, 2000). In contrast, I use this term normatively and prescriptively as a genuine dialogue about the teacher-student genuine guidance.
} 


\section{The relationship between education and learning and its consequences for dialogic pedagogy}

Eugene Matusov

ability brought down on me and helped me sort out tensions and temptations I had found myself in. This dialogic help would have made my reading insight much more educational than it actually was.

Finally, dialogic pedagogy can help to promote the critical educational appreciation of the student's learning and/or insight. For example, my studies and dialogue with my colleagues about literacy and orality helped me develop ambivalence, if not, at times, apprehension about my own and other people's literacy (Matusov \& St. Julien, 2004). Dialogue can promote a critical examination of the student's learning and insights with regard to its desirability, the PROs, the CONs, the unexpected side effects, the underlying values, and its "hidden curriculum" (i.e., the invisible but consequential socialization on unexamined values).

\section{References}

Bakhtin, M. M. (1999). Problems of Dostoevsky's poetics. Minneapolis: University of Minnesota Press.

Berlin, I., \& Hardy, H. (2002). Freedom and its betrayal: Six enemies of human liberty. Princeton, N.J. Chichester: Princeton University Press.

Biesta, G. (2010). Good education in an age of measurement: Ethics, politics, democracy. Boulder, CO: Paradigm Publishers.

Biesta, G. (2020). Have we been paying attention? Educational anaesthetics in a time of crises. Educational Philosophy and Theory. doi:10.1080/00131857.2020.1792612

Bruner, J. (1986). Actual minds, possible words. Cambridge, MA: Harvard University Press.

Cline, S., \& Schwartz, D. (1999). Diverse populations of gifted children: Meeting their needs in the regular classroom and beyond. Upper Saddle River, NJ: Merrill.

DePalma, R., Matusov, E., \& Smith, M. P. (2009). Smuggling authentic learning into the school context: Transitioning from an innovative elementary to a conventional high school. Teacher College Record, 111(4), 934-972.

Dewey, J. (1902). The child and the curriculum and the school and society (Combined ed.). Chicago: University of Chicago Press.

Fábri, Z. (Writer). (1976). The fifth seal [VHS]. In Mafilm (Producer). Hungry: Facets Video.

Greenberg, D. (1991). Free at last: The Sudbury Valley School. Framingham, MA: Sudbury Valley School Press.

Hart, P. D. (2006). Report findings: Based on a survey among California ninth and tenth graders. Retrieved from http://www.connectedcalifornia.org/downloads/irvine poll.pdf

Hartman, D. E., \& Schmidt, S. L. (1995). Understanding student/alumni satisfaction from a consumer's perspective: The effects of institutional performance and program outcomes. Research in Higher Education, 36(2), 197217. doi:10.1007/BF02207788

Kant, I. (1784). An answer to the question: What is Enlightenment? Retrieved from https://www.stmarysca.edu/sites/default/files/attachments/files/Kant--What\%20ls\%20Enlightenment .pdf

Ladson-Billings, G. (1995). Toward a theory of culturally relevant pedagogy. American Educational Research Journal, 32(3), 465-491.

Lave, J. (1988). Cognition in practice: Mind, mathematics, and culture in everyday life. Cambridge, UK: Cambridge University Press.

Lave, J. (1992, April). Learning as participation in communities of practice. Presented at the meeting of the American Educational Research Association. Retrieved from http://www.udel.edu/educ/whitson/897s05/files/Lave92.htm

Lave, J., \& Wenger, E. (1991). Situated learning: Legitimate peripheral participation. Cambridge, UK: Cambridge University Press.

Lemke, J. L. (1990). Talking science: Language, learning, and values. Norwood, NJ: Ablex Pub. Corp.

Maier, S. F., \& Seligman, M. E. (1976). Learned helplessness: theory and evidence. Journal of experimental psychology: general, 105(1), 3-46.

Maier, S. F., \& Seligman, M. E. (2016). Learned helplessness at fifty: Insights from neuroscience. Psychological review, 123(4), 349-367.

Mark, S. F. (1983). To succeed or not to succeed: A critical review of issues in learned helplessness. Contemporary Educational Psychology, 8(1), 1-19.

Matusov, E. (2009). Journey into dialogic pedagogy. Hauppauge, NY: Nova Science Publishers. 


\section{The relationship between education and learning and its consequences for dialogic pedagogy}

Eugene Matusov

Matusov, E. (2020a). Elever og lærere som autorer i en bakhtinsk kritisk dialog (Students and teachers as authors in a Bakhtinian critical dialogue). In O. Dysthe, I. Johanne Ness, \& P. O. Kierkegaard (Eds.), Dialogisk pædagogik, kreativitet og læring (Dialogic pedagogy, creativity, and learning) (pp. 177-215). Åarhus, Denmark: KLIM.

Matusov, E. (2020b). Envisioning education in a post-work leisure-based society: A dialogic perspective. New York: Palgrave.

Matusov, E. (2020c). A student's right to freedom of education and a teacher's fiduciary obligation to support it: Reply to the commentaries. Dialogic Pedagogy: An International Online Journal, 8, SF97-SF114. doi:10.5195/dpj.2020.357

Matusov, E. (2020d). A student's right to freedom of education. Dialogic Pedagogy: An International Online Journal, 8 , SF1-SF28. doi:10.5195/dpj.2020.356

Matusov, E. (2021, in press). Promoting an educational culture of democratic dialogic education: Teacher as a benevolent dictator. Dialogic Pedagogy: An International Online Journal.

Matusov, E. (2021, submitted). Progressive education is the opium of the educators. Integrative Psychological and Behavioral Science.

Matusov, E., Baker, D., Fan, Y., Choi, H. J., \& Hampel, R. L. (2017). Magic Learning Pill: Ontological and instrumental learning in order to speed up education. Integrative Psychological and Behavioral Science, 51(3), 456-476. doi:10.1007/s12124-017-9384-8

Matusov, E., DePalma, R., \& Smith, M. P. (2010). The creation and maintenance of a 'learning-loving minority' in conventional high schools: A research-based response to John Ogbu. Oxford Review of Education, 36(4), 463-480.

Matusov, E., Marjanovic-Shane, A., \& Gradovski, M. (2019). Dialogic pedagogy and polyphonic research art: Bakhtin by and for educators: Palgrave Macmillan.

Matusov, E., Marjanovic-Shane, A., \& Meacham, S. (2016). Pedagogical voyeurism: Dialogic critique of documentation and assessment of learning. International Journal of Educational Psychology, 5(1), 1-26. doi:10.17583/ijep.2016.1886

Matusov, E., \& St. Julien, J. (2004). Print literacy as oppression: Cases of bureaucratic, colonial, totalitarian literacies and their implications for schooling. TEXT: International Journal, 24(2), 197-244.

Matusov, E., \& Sullivan, P. (2020). Pedagogical violence. Integrative Psychological and Behavioral Science, 54(2), 438-464. doi:10.1007/s12124-019-09512-4

Matusov, E., von Duyke, K., \& Kayumova, S. (2016). Mapping concepts of agency in educational contexts. integrative Psychological and Behavioral Science, 50(3), 420-446. doi:10.1007/s12124-015-9334-2

Mehan, H. (1979). Learning lessons: Social organization in the classroom. Cambridge, MA: Harvard University Press.

Moll, L. C., Amanti, C., Neff, D., \& González, N. (1992). Funds of knowledge for teaching: Using a qualitative approach to connect homes and classrooms. Theory into Practice, 31(2), 132-141.

Plato, \& Riddell, J. (1973). The Apology of Plato, with a revised text and English notes, and a digest of Platonic idioms. New York: Arno Press.

Resnick, L. B. (1987). Education and learning to think. Washington, DC: National Academy Press.

Rietmulder, J. (2019). When kids rule the school: The power and promise of democratic education. Gabriola Island, Canada: New Society Publishers.

Rogoff, B., Matusov, E., \& White, C. (1996). Models of teaching and learning: Participation in a community of learners. In D. R. Olson \& N. Torrance (Eds.), The handbook of education and human development: New models of learning, teaching and schooling (pp. 388-414). Malden, MA, US: Blackwell Publishers Inc.

Rousseau, J. J. (1979). Emile: or, On education. New York: Basic Books.

Sánta, F. (1986). The fifth seal: A novel (A. Tezla, Trans.). Budapest: Corvina.

Sidorkin, A. M. (2002). Learning relations: Impure education, deschooled schools, \& dialogue with evil. New York: P. Lang.

Sinclair, J. M., \& Coulthard, M. (1975). Towards an analysis of discourse: The English used by teachers and pupils. London: Oxford University Press.

Skidmore, D. (2000). From pedagogical dialogue to dialogical pedagogy. Language and Education, 14(4), 283-296.

Snijders, I., Wijnia, L., Rikers, R., \& Loyens, S. (2019). Alumni loyalty drivers in higher education. Social Psychology of Education, 22, 607-627. doi:10.1007/s11218-019-09488-4 
The relationship between education and learning and its consequences for dialogic pedagogy Eugene Matusov

Yazzie-Mintz, E. (2006). Voices of students on engagement: A report on the 2006 High School survey of student engagement. Retrieved from http://letsgetengaged.wikispaces.com/file/view/HSSSE 2006 Report.pdf

\section{(cc) EY}

New articles in this journal are licensed under a Creative Commons Attribution 4.0 United States License.

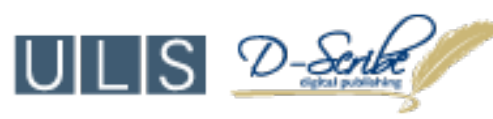

This journal is published by the University Library System, University of Pittsburgh as part of its D-Scribe Digital Publishing Program and is cosponsored by the University of Pittsburgh Press. 